Ecomorphology of fishes 
Developments in environmental biology of fishes $\mathbf{1 6}$

Series Editor

EUGENE K. BALON

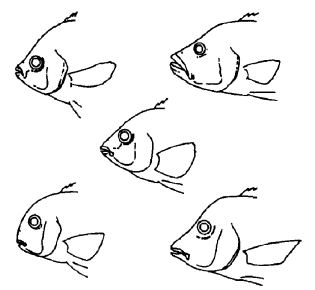




\section{Ecomorphology of fishes}

\section{Editors:}

JOSEPH J. LUCZKOVICH, PHILIP J. MOTTA, STEPHEN F. NORTON \& KAREL F. LIEM

Reprinted from Environmental biology of fishes 44 (1-3), 1995

with addition of species and subject index 
Library of Congress Cataloging-in-Publication Data

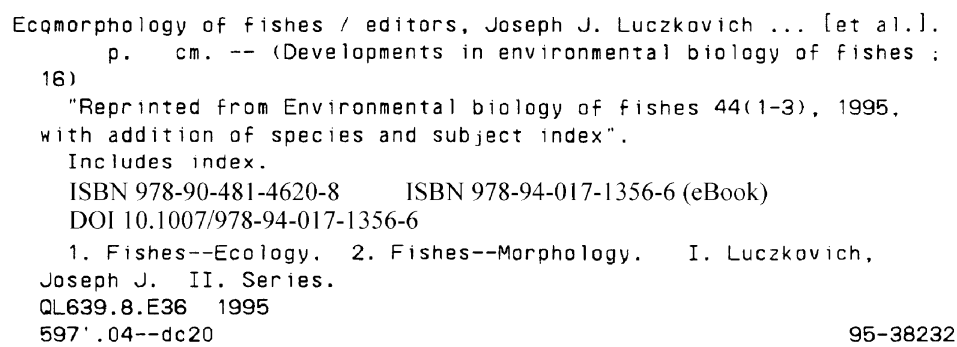

ISBN 978-90-481-4620-8

Cover design by Eugene Balon

was inspired by Daniel Pauly's (1994) essay Why didn't I think of this? in the book On the sex of fish and the gender of scientists (Chapman \& Hall, London), and is based on figure 9.1.

\footnotetext{
All Rights Reserved

(C) 1995 Springer Science+Business Media Dordrecht

Originally published by Kluwer Academic Publishers in 1995

No part of the material protected by this copyright notice may be reproduced or utilized in any form or by any means, electronic or mechanical, including photocopying, recording or by any information storage and retrieval system, without written permission from the copyright owner.
} 


\section{Contents}

Prelude to ecomorphology of fishes

by E.K. Balon \& K.F. Liem

\section{Introduction}

Perspectives on the ecomorphology of bony fishes

by P.J. Motta, S.F. Norton \& J.J. Luczkovich

\section{Review}

Development of ecomorphology of fishes in Russia, by S.A. Smirnov, A.P. Makeyeva \&

A.I. Smirnov

\section{Full papers}

Ecomorphological correlates in ten species of subtropical seagrass fishes: diet and microhabitat utilization, by P.J. Motta, K.B. Clifton, P. Hernandez \& B.T. Eggold

A functional approach to ecomorphological patterns of feeding in cottid fishes, by

\section{S.F. Norton}

The influence of oral anatomy on prey selection during the ontogeny of two percoid fishes, Lagodon rhomboides and Centropomus undecimalis, by J.J. Luczkovich, S.F. Norton \& R.G. Gilmore, Jr.

Predicting patterns of prey use from morphology of fishes, by P.C. Wainwright \&

B.A. Richard

Ecomorphology of retinal structures in zooplanktivorous haplochromine cichlids (Pisces) from Lake Victoria, by H.J. van der Meer, G.Ch. Anker \& C.D.N. Barel

Ecomorphological adaptations to bioluminescence in Porichthys notatus, by A.F. Mensinger

Ecomorphology of solitary chemosensory cell systems in fish: a review, by K. Kotrschal

Tradeoffs between respiration and feeding in Sacramento blackfish, Orthodon microlepidotus, by J.J. Cech, Jr. \& M.J. Massingill

Time and tide wait for no fish: intertidal fishes out of water, by K.L.M. Martin

Papyrus swamps and the respiratory ecology of Barbus neumayeri, by L.J. Chapman \& K.F. Liem

Morphology, mechanics, and locomotion: the relation between the notochord and swimming motions in sturgeon, by J.H. Long, Jr.

Evolutionary interplay between ecology, morphology and reproductive behavior in threespine stickleback, Gasterosteus aculeatus, by S.A. Foster \& J.A. Baker

Armor morphology and reproductive output in threespine stickleback, Gasterosteus aculeatus, by J.A. Baker, S.A. Foster \& M.A. Bell

Ecomorphological diversification and convergence in fluvial cichlid fishes, by

K.O. Winemiller, L.C. Kelso-Winemiller \& A.L. Brenkert

Phylogenetic systematics and biomechanics in ecomorphology, by M.W. Westneat

\section{Summary}

The role of ecomorphological studies in the comparative biology of fishes, by S.F. Norton, 